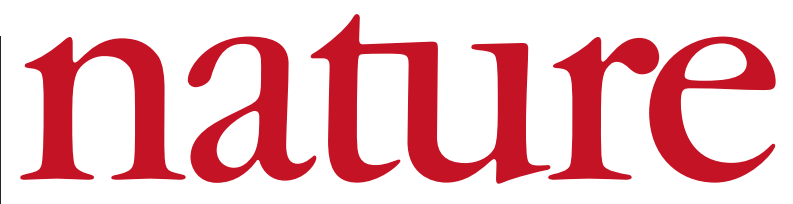

9 May 2002 Volume 417 Issue no 6885

\title{
US should back research cloning
}

The US Senate is expected to vote on legislation that would ban cloning by the end of this month. Supporting cloning for research is both right and in the national interests of the United States.

A $s$ technology continues to advance, countries must decide how they will deal with the issue of human cloning for reproduction or research. So far, several nations have placed strong restrictions on therapeutic cloning; others are moving towards such restrictions, and a few have staked out positions in favour of therapeutic cloning. After months of acrimonious debate, the United States must now decide what it will do.

All legislators can agree that it would be wrong now to make a walking, talking, real-life human clone. The National Academy of Sciences also supports that position. But its Institute of Medicine has rightly said that its objections to the safety of reproductive cloning do not apply to research cloning. Indeed, some scientists say that research cloning could yield stem cells that could be used to grow therapeutic tissues for patients with diseases such as Parkinson's. They also say that studying stem cells made from the cells of diseased patients could help us understand why people with the same genetic make-up get sick or stay well.

Opponents of research cloning say there is no proof that it will yield any cures. They also say that adult stem cells are more promising and less controversial. They have gained Congressional and public support by tapping into widespread fears about biotechnology, which some worry is careening quickly down a slippery slope towards the commodification of the human species. But such fears do not represent a sensible basis for a ban on research cloning, which is likely to give insights into the processes that underlie a host of debilitating diseases (see Nature 414, 567; 2001).

The Senate is now moving towards a showdown on this issue. Two bills have been introduced. Senator Sam Brownback (Republican,
Kansas) introduced a bill that would ban cloning for any purpose. His rivals, led by Senator Dianne Feinstein, (Democrat, California), have introduced competing legislation that would allow scientists to clone embryos for research. And senators eager to air their views on the issue are calling for a vote on the matter in the next few weeks. Brownback is said to have nearly 50 supporters, but for technical reasons a bill is unlikely to be passed unless 60 senators support it.

Advocates of therapeutic cloning have outlined scenarios that would make the Senate more likely to pass a bill that would allow research cloning, such as amending the Brownback bill to allow research. In this way, senators could save face by simultaneously voting for Brownback and for research.

However, any bill that does pass the Senate must be reconciled with the House bill in a conference. The Brownback bill is virtually identical to a House cloning ban that was passed last July. So it would speed through the conference committee. But Senate and House negotiators are unlikely to compromise if the Senate votes to allow therapeutic cloning. So the result of this month's Senate debate is likely to be either that President Bush signs a bill that bans cloning for any purpose, or that he does not sign any cloning bill at all. The issue could also spill over into the appropriations process this autumn, when senators try to force rules through the Congress by attaching them to necessary spending bills.

The Congress has strongly supported the National Institutes of Health in recent years because it wants the United States to be a world leader in biomedical research. The Senate should continue its strong support of biomedical science, and act in the national interest, by refusing to pass a ban on research cloning.

\section{Peer review reviewed}

\section{A controversial change to the peer-review process of Germany's principal funding agency is long overdue.}

T he Deutsche Forschungsgemeinschaft (DFG), Germany's main funding agency, is symbiotically embedded in the German scientific community. Its referees, who decide which research to fund, are elected every four years in a process led by scientific societies and involving all tenured researchers.

This system means that researchers by and large have confidence in 'their' agency. But it has not kept pace with the development of science. The DFG senate therefore agreed this week on a reform, which — if approved by the general assembly in July — will strengthen the initiative of the DFG's programme managers and bring additional expertise to the reviewing process.

Predictably, there is friction. Some interpret the move as a turn away from democratic ideals, or a presumptuous attempt to increase the power of the DFG's bureaucratic machinery. But such responses are misplaced. The 650 elected referees cannot cope with the growing complexity of science, nor with the 20,000 or so grant applications every year. Reviewing procedures take too long, interdisciplinarity gets short shrift, and unconventional or risky projects have little chance of funding.
In recent years the DFG has called in a growing number of additional experts, both from Germany and from abroad, to support the reviewing process. In future, if the new proposals are approved, this will become the rule. The DFG's programme managers, who are respected scientists themselves, work cheek-by-jowl with the scientific community and tend to be good at overseeing developments in fast-moving fields. The DFG's elected referees will still have the final say, and will be able to scrutinize the administrators' choice of reviewers.

In reviewing its processes, the DFG also hopes to create an additional bottom-up stimulus to its funding priorities. The reform should bring the agency closer to common international standards. It will hardly revolutionize the German science system, but it is perhaps a long-awaited sign that the system is becoming more dynamic, and more accepting of new scientific ideas. The quality of science, and Germany's attractiveness to foreign scientists, can only benefit. The DFG has shown that it is willing to shift. Its general assembly and the community at large should welcome the changes. 